\title{
Dance Anthropology and the Impact of 1930s Haiti on Katherine Dunham's Scientific and Artistic Consciousness
}

Hannah Durkin, University of Nottingham

\begin{abstract}
Katherine Dunham (1909-2006) was one of the most critically and commercially successful dancers of the twentieth century. She established and ran the Katherine Dunham Dance Company, the earliest self-supporting predominantly black dance company and one of the first modern dance troupes to achieve international success. She was also one of the first African Americans to conduct anthropological fieldwork, and the first anthropologist to explore the function of dance in rituals and community life. Her observations of dance rituals whilst working as a graduate researcher in 1930s Haiti played a formative role in her dance. Her choreographic method combined Caribbean cultural forms with ballet and modern dance practices and has had a profound but rarely acknowledged influence on twentieth-century dance. This article examines Dunham's anthropological memoir, Island Possessed (1969), to explore the formative role that Haiti played on Dunham's scientific and artistic consciousness. It contends that Island Possessed articulates a highly reflexive engagement with ethnography, re-envisaging anthropological research as a space of intercultural exchange. It shows how the text sheds light on a lifelong project by Dunham to enact an artistic and cultural legitimisation of Haiti by incorporating its ritual dance forms onto the concert dance stage, an endeavour that would ensure a significant Haitian influence over North American dance throughout the midtwentieth century.
\end{abstract}




\section{Keywords}

Katherine Dunham, Haiti, dance, anthropological inquiry, participant observation, intercultural exchange

The explosion of modernism in the 1920s and 1930s precipitated a primitivist vogue throughout the French- and Anglo-Atlantic worlds, in which the Caribbean, and the former French colony of Haiti in particular, became a key site of exotic desire. At the same time, many African American writers and artists turned to Haiti, the first independent black republic, in an attempt to reclaim their cultural heritages (Polyné 2010: 155). Although her work has been widely overlooked, African American dancer-anthropologist Katherine Dunham (1909-2006) is a crucial figure in understanding the tensions between primitivist fascinations with the black body and a burgeoning international black consciousness. In 1935, she secured a grant from the Scholarship Committee of the Rosenwald Fund to support an eighteenth-month trip researching Caribbean dances in their social contexts by recreating some of the dance movements she hoped to observe. Making her case for the first trip of its kind, Dunham outlined an intention to explore cultural links between Caribbean and United States dance forms, a relationship which would later play a prominent role in her choreography. By adopting the role of an ethnographer, a branch of anthropology directed towards the scientific observation and classification of human societies, Dunham was entering into a history of power relations that had dehumanized the black new world, and Haiti in particular, as a passive subject for the popular consumption of European and United States spectators. But by choosing to act out and thus to embody the dances she hoped to observe, Dunham gave clues to a 
fieldwork technique of physical participation that was to reconfigure observer-subject hierarchies and lead to the creation of a pioneering cross-cultural artistic practice.

Katherine Dunham was one of the most critically and commercially successful dancers of the twentieth century. She was the first choreographer to establish a selfsupporting, predominantly black dance company, and she developed a unique dance style that blended European patterns with African American and Caribbean vernacular forms. The Katherine Dunham Dance Company performed on Broadway and in film, and Dunham became one of the first African American performers to gain serious critical attention (Johnson 2005: 3). The Company also became one of the first modern dance troupes to achieve international success when it toured Europe in the late 1940s. For the next two decades, it performed to great attention and acclaim in sixty-seven countries as the largest independent dance company in the world. Prior to her performative success, however, Dunham worked as an anthropologist specializing in Caribbean dance rituals. Along with folklorist Zora Neale Hurston (1891-1960), she was one of the first African Americans to conduct anthropological fieldwork, and the first anthropologist to explore in detail the function of dance in rituals and community life. Dunham's observations and experiences in the Caribbean in the mid-1930s shaped her understanding of non-European-derived dance forms. Her work in Haiti had the most prolonged and profound impact, as her participation in the ritual practices of the island's folk religion Vodoun ${ }^{1}$ inspired her to develop an egalitarian choreographic method of intercultural exchange that would transform international dance practices.

\footnotetext{
${ }^{1}$ Vodoun is a common current spelling of the term, but it can also be spelled vodun, vaudou, vodou, vaudun, vaudoun, or voodoo.
} 
Dunham arrived in the Caribbean in 1935 with the then unusual objective of developing an anthropological understanding of local dance patterns. Although fieldworkers such as Melville Herskovits (1895-1963) had already begun to investigate the cultural significance of dance practices, Dunham was the first researcher to make dance the primary focus of her investigation. She visited Jamaica, Martinique and Trinidad but she spent sixteen months of her visit in Haiti. Dunham's work in Haiti should be understood in light of longstanding fears of and fascinations with the nation as a 'primitive' other. As Kate Ramsey acknowledges, '[s]ince the late eighteenth century, Haiti had been constructed in the West as an imaginative space signifying atavistic magic, savagery, and sensuality' (1997: 358). A particularly notorious example of such literature was Sir Spenser St. John's Hayti: Or, the Black Republic, which described rural communities as spaces consumed by 'fetish worship and cannibalism' (1884: vi). Such associations were exacerbated in the United States imagination following the country's decision to occupy the island in 1915 . One of the earliest and most influential ethnographic tracts on Haiti was William Seabrook's Magic Island (1929), whose lurid description of the figure of the zonbi (zombie) had an immediate and lasting effect on United States popular culture. Thus, Millery Polyné identifies an 'anthropological imagination' of Haiti rooted in colonial and neocolonial ethnography, in which 'Africa', 'Vodoun' and 'Race' became key symbols with dance serving as the central image of these associations (2010: 155).

Dunham's first-hand engagement with Haitian ritual practices would lead to a profoundly different articulation of the island's dance forms, however. By literally embodying the dances she observed, Dunham succeeded in establishing a close physical relationship with her subjects that transcended traditional scientist-subject hierarchies, and which would form the basis of her intercultural dance practice. This 
physical closeness to her hosts would also be explored in detail in her ethnographic writings, most notably in her description of her initiation into Vodoun in her memoir of her Haitian experiences, Island Possessed (1969).

In Island Possessed, Dunham expresses a sense of intimate connection with her subjects because dance enables her to take part in the rituals she observes and to achieve cultural integration. Her arrival in Haiti can be read as the beginning of a rich mutual exchange in which the host nation problematizes its status as scientific subject by claiming power and influence over the observer. This sensation of communality through dance is particularly relevant to studies of Dunham's wider cultural impact because her choreography is an important site of cross-cultural amalgamation and exchange. As Ramsey notes,

In the late 1930s, choreographer/anthropologist Katherine Dunham ... develop[ed] a modernist concert dance idiom based on Afro-Haitian and Caribbean forms that not only contributed to widespread interest in and travel to Haiti in the 1940s and 1950s but also ensured that elements of African diasporic performance came to permeate North American concert dance (1997: 359).

Despite Dunham's pioneering dance work and her almost unique status as an African American woman anthropologist working in the 1930s, her writings have received very little critical attention. Her enduring relationship with Haiti and her involvement in the Black Arts Movement in the 1960s have been almost completely forgotten. This essay focuses on Island Possessed to investigate the formative role that Dunham's Haitian research trip played on her scientific and artistic consciousness. Building on Daphne's Lamothe's argument that Dunham's writings 
were part of 'a tradition of feminist ethnography that makes explicit issues of positionality and is more ambivalent, and therefore implicitly critical, about claiming the ethnographer's scientific authority' (2008: 120), this article will show that, in Island Possessed, Dunham positions herself as a self-conscious narrator, who engages with and is yet complicit in scientific objectification but who, through religious worship and dance, physically immerses herself into Haitian culture. In her work, Island Possessed, she reconfigures anthropological investigation by blurring the boundaries between self and other in order to facilitate cultural exchange. The text sheds light on Dunham's lifelong project, by which she sought to realize an artistic and cultural legitimisation of Haiti by incorporating its ritual dance forms onto the concert dance stage, an undertaking that would position her as a key player in the Black Arts Movement and ensure a significant Haitian influence over North American dance practices throughout the mid-twentieth century.

Dunham's Haitian experiences had a demonstrable impact on her cultural philosophy and artistic legacy. Island Possessed recounts her experiences as a graduate researcher in dance and anthropology during the mid-1930s in Haiti, shortly before she postponed her academic training to pursue a career on stage and screen. As well as describing her interactions with key political figures, including future Haitian presidents Dumarsais Estimé (1900-1953) and François 'Papa Doc' Duvalier (1907-1971), the text describes her engagement with religious and community rituals, including a Mardi Gras ceremony and the spirit transfer of a bocor, a Vodoun priest who practices divining and/or magic and works with the loa (a spirit who mounts a worshipper during a ceremony) and the dead. In particular, much of the text is devoted to Dunham's first-hand experience of a lavé-tête, a ritual marking the point of entry into Vodoun. In this regard, Island Possessed represents a textual extension of 
Dunham's 1947 Master's thesis, 'Dances of Haiti: Their Social Organization, Classification, Form, and Function', in which she discusses Haitian dance rituals and evaluates their religious and psychological significance. ${ }^{2}$ Dorothea Fischer-Hornung has described 'Dances of Haiti' as 'among the founding texts on the anthropology and aesthetics of Vodoun' (2008: 347). She observes that, like her contemporary Zora Neale Hurston and protégée Maya Deren (1917-1961), Dunham 'attempted to decipher the meaning of Vodoun [...] for the community of practitioners, for nonpractitioners, as well as for themselves in the context of their lives as scholars and artists' (Fischer-Hornung 2008: 347).

Nevertheless, Island Possessed goes much further than 'Dances of Haiti' in its engagement with Vodoun. Written in Senegal in the 1960s and published in 1969, more than thirty years and thousands of miles from the experiences that it describes, its temporal dislocations from its island subject - and from its narrative experiences help to situate it as a highly self-reflexive text. Dunham wrote Island Possessed after returning from Haiti to enjoy a lengthy international dance career and also at the end of the United States Civil Rights Movement, a period during which she fought personal battles against racial injustice. ${ }^{3}$ In this work, the narrative of her original

2 'Dances of Haiti: Their Social Organization, Classification, Form, and Function' was submitted to the Department of Anthropology at the University of Chicago in 1937 in partial fulfilment of a masters degree that Dunham did not immediately complete. It was translated and published in Spanish (Las danzas de Haiti, 1947), and French (Les danses d'Haïti, 1950), before finally being published in English as Dances of Haiti in 1983.

${ }^{3}$ Dunham's stance against racial segregation and injustice preceded the Civil Rights Movement. On 19 October 1944, she announced her anger on stage at performing 
observations is augmented, and even challenged, by the reflections of an older and arguably wiser self. For instance, the older narrator confronts her youthful self's familial and admiring relationship with future Haitian President Estimé by considering his decision, prior to his deposition in 1950, to praise the violent actions of his supporters, and concludes that, '[c]oncerning Dumarsais Estimé I am left in doubt about many things' (56). Dunham's thesis minimizes the position of the observer and favours scientific language; it represents a deliberate adherence to scholarly discourse that situates Dunham's Haitian trip as an observational project. In contrast, Island Possessed adopts an autobiographical narrative strategy by presenting a candid account of Dunham's experiences on the island and her immersion in Vodoun. While, on the one hand, 'Dances of Haiti' presents a key scientific contribution to Haitian dance rituals, on the other, Island Possessed incorporates the author into the dance forms she observes. In so doing, she positions Caribbean folk rituals as sites with profound psychological and social significances to their practitioners.

Dunham's engagement with Vodoun in Island Possessed therefore reveals not only a struggle to translate and to comprehend but, and unusually for its time, an attempt to integrate into Haitian culture. Dunham arrived on the island as a student of Herskovits, one of the first scholars to uncover and recognize the importance of African survivals in the Americas. Herskovits trained Dunham with the purpose of identifying African styles of dance in Haiti, Jamaica, Trinidad and Martinique. He prepared her for this role by instructing her in his anthropological method. He showed her how to be unobtrusive by acting as an unassuming, selfeffacing presence within the community, thereby maximizing her chances of gaining 1950 and 1953 she staged Southland, a ballet about lynching. 
cultural acceptance and inclusion. However, Herskovits's instructions and training methods were not intended to facilitate social and cultural interaction, but instead represented a means of obtaining detailed research. Dunham's Haitian project was founded on achieving scientific integrity; her interpretations were meant to represent authoritative descriptions of the subjects she had been assigned to observe. James Clifford notes that, in classical ethnography, 'the author's personal voice is seen as a style in the weak sense: a tone, or embellishment of the facts' (1986: 13). Thus, '[s]tates of serious confusion, violent feelings or acts, censorships, important failures, changes of course, and excessive pleasures are excluded from the published account' (Clifford 1986: 13).

But much of Dunham's success in Haitian society was made possible by her willingness to transgress many different boundaries, including the class, gender and cultural differences that separated her from her hosts. In choosing to experience firsthand a lavé-tête rite, Dunham acted out a level of interaction that would now be termed 'participant observation', a method of cultural immersion in which the participant nevertheless retains the role of scientific recorder. Although this method of anthropological analysis predates Dunham's work, Halifu Osumare notes that Dunham's adoption of this approach through first-hand experience of a Vodoun initiation was unusually embracive. Osumare writes, '[a]lthough the culturalrelativist, participant-observation technique had been the theorized anthropological method since [Franz] Boas, her professors were clearly taken aback at the fervor in which she employed participatory fieldwork techniques' (2005: 617). Specifically, Osumare refers to a 1936 letter from Melville Herskovits, in which he expresses concern over Dunham's level of cultural immersion and writes, '...I am a little disturbed ... at the prospect of your going through canzo ceremony [a trial by fire 
that marks the participant's initiation into the second stage of Vodoun], and I am wondering if it would not be possible for you to attend merely as a witness... [author's italics]' (2005: 617).

Dunham's immersion method is enacted most explicitly via bodily experience, most notably through ritual and dance. James Clifford argues that, '[p]articipant observation obliges its practitioners to experience, at a bodily as well as an intellectual level, the vicissitudes of translation [emphasis added]' (1988: 23-24). The experiences of the observer are therefore channelled through shared bodily contact, and subjective physical sensation becomes a site of interpretation. Ursula Rao and John Hutnyk argue that anthropological texts 'originate from the memory of bodily participation in dialogue and reflect the knowledge that it generates' (2006: 2). Klaus-Peter Köpping suggests that anthropological understanding is only truly possible when it is based on meaningful two-way bodily communication, in which the anthropologist self-consciously confronts their position of Otherness or alienation within the community, thus giving in to their inferior social status. He asserts that, 'the writing of ethnography should not degenerate into the mere technology of translation, but must be a creative act. It can only be so if there was true corporeal dialogue' (Köpping 2002: 216). By bodily participating in her hosts' community through active engagement in a Vodoun ceremony, Dunham therefore abandons traditional methods of scientific detachment in favour of meaningful cultural inclusion.

Through physical closeness and communal activity, Dunham confronts the intrinsic modernity of black new world societies, which her tutors failed to recognize. Dunham was taught to read her observations as evidence of an African past, rather than as dynamic cultural practices with an ongoing social function and meaning. 
Pioneering anthropologists such as Herskovits and Franz Boas (1858-1942) were more interested in the survivalist elements of Caribbean cultures than in reading them as ongoing intellectual processes or as psychological responses to present circumstances. In a 1941 article, 'Form and Function in Primitive Dance', Dunham suggested that Haiti was chosen as the central focus of her investigation because it was believed that 'the preservation of authentic and original forms was more characteristic of Haiti than of other islands of the West Indies', and because it was felt that, 'the authentic context within which the interrelation of the forms and functions of the dances would most spontaneously manifest themselves was available to me' ([1941] 2005: 502). Herskovits and his contemporaries read cultural practices in historical terms, therefore helping to reinforce an illusory concept of cultural purity and disregarding the Black Atlantic as a key site of modernity.

Unlike Herskovits, Dunham sought to understand dance practices of the black new world in their contemporary social contexts. As Joyce Aschenbrenner asserts, 'Dunham's objective was not merely to record dances and make good films but also to understand the social role of dance' (2002: 61), and she expressed dismay when Herskovits read her recording of the Jamaican Koromantee, a dance that she believed to hold cultural and historical significance, as 'that picture where men are hopping about very fast' (2002: 61). Dunham arrived in Haiti in 1935, just one year after the island emerged from nearly two decades of United States occupation, and the same year in which Aimé Césaire (1913-2008) coined the term 'Négritude' to describe the international black ideology emerging as a response to French colonial racism. Dunham claimed that, although she took her 'guidance in political thinking and intellectual and conscious awakening for granted' (46) and therefore did not realize it at the time, Estimé introduced her to the concept of Négritude. Although she 
ultimately disowns the term for 'so easily bordering on nationalism' (47), by concluding that 'I do not admit to a spiritual or cultural poverty in black people which would make it necessary to coin a word or system of thinking of oneself outside the human division' (4-5), Dunham admits to having been influenced by Estimé, who introduced her to the movement. She writes, 'I must have practiced, preached, and lived [Négritude] (4)', and she describes Estimé's influence on her growing racial awareness, noting how his outlook had succeeded in 'awakening a conscience which had been selfish, not social' (42) and therefore in imbuing her scientific mind with social consciousness. Likening Estimé to Haitian independence hero Toussaint L'Ouverture (1743-1803), she writes,

It was now up to me to turn this thirst for knowledge to a way to service, as Estimé's ambition was not for self, but for service ... Gradually, I began to see the things around me with his eyes, with his evaluations, though never losing the intense preoccupations with what I had come to Haiti for, the vaudun and the complex surrounding it (42).

As Island Possessed evidences, Estimé's socially conscious approach to Haitian politics directly inspired Dunham to contemplate the humanities of her subjects and to treat her presence on the island as a long-term commitment both to individuals and to complex cultural rites.

In its self-conscious engagement with a modern black consciousness, Island Possessed parallels the work of one of the few other African American anthropologists of the 1930s, Zora Neale Hurston. Halifu Osumare lists Hurston as perhaps the only other African American anthropologist of the 1930s (2005: 622). 
Osumare's observation omits the work of Lawrence Brown (1893-1972), who collected and arranged spirituals, and Eslanda Goode Robeson (1896-1965), whose memoir African Journey (1946) describes her experiences as an anthropologist in Africa in the 1930s, but it underscores the rarity of Dunham and Hurston's statuses as African American women fieldworkers at this time (2005: 622). Both Dunham and Hurston conducted research in Haiti in 1936, and as David Murray notes, Hurston's literary record of her experiences, Tell My Horse (1938), reveals an unusual selfreflexivity: 'Her use of fictional techniques, variously combined with the standard forms of objective ethnography, has been seen as anticipating the "reflexive" anthropology of later years' (2007: 88). Like Dunham, therefore, Hurston's uncertain and ambiguous narrative voice can be read as a self-conscious questioning of the ethnographer's ability to provide an authoritative account of her subjects. Moreover, Murray suggests that Tell My Horse's close engagement with Vodoun - also a fundamental component of Dunham's ethnographic writing - was unusually immersive for its time and in this regard foreshadowed more recent forms of anthropology:

Anthropology has tended to deal with native belief in magic, witchcraft, and the like from outside rather than phenomenologically, and one of the significant ways in which Hurston anticipates later ethnographies is her direct involvement in hoodoo and voodoo practices (2007: 89).

Dunham's involvement in Haiti had even greater cultural significance - and articulated an even more explicit cultural sensitivity - than Hurston's work, however. For, as Murray also observes, unlike Hurston, whose anthropological work in Haiti 
was ultimately fleeting, Dunham's fieldwork was 'the beginning of a long association with Haiti and a whole series of initiations' (2007: 93). Far exceeding her position as scientific observer of Vodoun rites, Dunham would eventually become permanently entrenched in Haitian cultural life, later achieving the rank of mambo (priestess) in the religion, and purchasing Habitation Leclerc - the former home of Napoleon's sister Pauline Bonaparte Leclerc - as a second home in the late 1940s. Unlike her colonial predecessor, Dunham used her home as a medical facility (Dunham [1969] 1994: 266-70). A lifelong campaigner for Haitian rights, in 1992, at the age of 82 , she embarked on a 47-day hunger strike to protest the injustices of the United States's forced repatriation of Haitian refugees who were fleeing the military coup that overthrew President Jean-Bertrand Aristide (1953-). Lamothe asserts that, 'Hurston seemed unable or unwilling to get close to any individuals other than the urban elite and American expatriates that she relied on as her informants' (Lamothe 2008: 142). In stark contrast, Dunham enjoyed close friendships throughout the Haitian lowerclass community, demonstrating a deliberate social flexibility and one which she emphasized in Island Possessed.

Early in Island Possessed, Dunham describes an almost effortless cultural integration into Haiti. As an American social scientist, but also as a light-skinned African American woman, she discovers that her status in Haiti is fluid and adaptable, and finds herself at times treated as an outsider, and at others as an insider in the many divisions of Haitian society. Reflecting on her fluctuating status, she writes:

Of my kind I was a first - a lone young woman easy to place in the clean-cut American dichotomy of color, harder to place in the complexity of Caribbean color classifications; a mulatto when occasion called for, an in-between, or 
'griffon' actually, I suppose; most of the time an unplacable, which I prefer to think of as 'noir' - not exactly the color black, but the quality of belonging with or being at ease with black people when in the hills or plains or anywhere and scrambling through daily life along with them (4).

By positioning her status within Haiti as ambiguous, Dunham here destabilizes racial and cultural identities by contrasting Haiti's system of racial classification with that of the United States's polarized conceptualisations of 'blackness' and 'whiteness'. In so doing, she reveals a flexibility of identity on the island - which she hints would be impossible within America itself - that enables her to occupy several social positions at once and to not only observe, but also to immerse herself within various different social groups and keep meanings and subject positions circulating.

This observation is not intended to overlook Haiti's complex caste system, according to which a person's social standing on the island would frequently be determined by skin tone, and whose oppressive and discriminatory effects Dunham delineates in detail in Chapter One of Island Possessed. Instead, it is to suggest that Dunham's illumination of an alternative perception of racial difference from that practised in the United States - as well as her inability to fit comfortably within it highlights the highly subjective and arbitrary nature of racial categorisation. In Island Possessed, Dunham is highly conscious of the limits of her powers as a scientific observer, as she engages self-reflexively with her narrative authority in order to contest cultural hierarchies. By exploring first-hand a range of social positions in Island Possessed, Dunham indicates an awareness of the fluidity of identities, a slipperiness of social positioning that she would later explore physically through a dance practice based on intercultural exchange. 
Draft manuscripts of Island Possessed underscore the complex relationship between the text's scientific themes and its self-reflexive focus on shifting constructions of identity. A very early synopsis of Chapter Three dating back to July 1963, six years before the book was published, lists as intended topics 'Analysis of Vaudun and its importance in the life of the Haitian peasant; influence in life of entire island', but also 'Self examination; how much was in the spirit of scientific investigation'. These notes reveal that, as early as her first draft, Dunham wanted her text to function as a scientific work but also as a personal account of her Haitian experiences. In the 1950s, art critic Bernard Berenson (1865-1959) encouraged Dunham to write for publication, and psychologist Erich Fromm (1900-1980) suggested that she draw on her personal experiences for inspiration (Aschenbrenner 2002: 155). Dunham began writing as catharsis, and used the written form as a means of dealing with personal trauma, which included her first-hand experiences of racism, a troubled relationship with her father, and the institutionalisation and early death of her brother, Albert. In an early draft of Island Possessed, Dunham notes that the themes of her childhood memoir, A Touch of Innocence (1957), were so personal that when she wrote it, 'it had to be after the deaths of each immediate member of my family' (Dunham 1963). Likening her Vodoun experiences to the confessional nature of her memoir, Dunham refers to her initiation as 'an experience which I had never intended to write about [...] [but] I cannot wait for Haiti to die because Haiti will never die' (Dunham 1963). Dunham's unwillingness to write about Vodoun underscores the secretive nature of its rituals and the sacred trust that enabled her to experience them, at the same time that it highlights her emotional investment in these experiences. In writing about her initiation, Dunham emphasizes intersections between the private and public in her work, challenging self-other binaries by creating 
a written confession that, like her childhood memoir, recalls an encounter that had a profound psychological effect on her life and, indeed, her career.

Dunham interrogates her anthropological authority from the very beginning of Island Possessed. Describing her arrival on the island in the opening paragraph, she writes, '[i]t was with letters from Melville Herskovits, head of the Department of Anthropology at Northwestern University, that I invaded the Caribbean - Haiti, Jamaica, Martinique, Trinidad ... then Haiti again for the final stand for the real study' (3). This statement establishes Dunham first and foremost as a scientist, whose reputation has been authenticated by close association with a pre-eminent white male scientific authority. Dunham is recalling her rigorous scientific training to draw attention to the fact that she was sent to Haiti to conduct dispassionate research, not to get to know its people.

Dunham's choice of terminology insinuates a self-reflexive questioning of her position as scientist, however. In choosing to suggest that she has 'invaded' the Caribbean, Dunham engages with Haiti's troubled history as a former slave colony, also hinting at the US's recent controversial occupation of the island, which she later criticizes for having 'very little consideration for the customs, desires, and habits of the people themselves, and with no wish, until the harm was done, to find out what the national character was like' (24). By positioning herself as an invader too, she undermines the authority of her trip and the moral sanctity of her research. By comparing her anthropological work to an invasion, Dunham blurs the boundaries between scientific intervention and territorial expansion and conquest. She hints at the role that the rationale of 'science' has historically played in defining, and thus in subjugating and 'othering', colonial nations. Dunham's insights represent the reflections of an older woman who has enjoyed a close and enduring relationship with 
Vodoun, and she reveals a sense of ambivalence regarding her position as scientist that highlights the problematics of her place in a school of European American intellectualism which had made her trip possible but which also inculcated blindness to lived human experience.

Dunham describes herself as 'a perspiring student of "dance and anthropology" wondering what to do next, now that the first stage of the great adventure was out of the way' (9). By drawing attention to her physical awkwardness and inexperience, Dunham undercuts the commanding position that her previous emphasis on her scientific training implied. In wondering 'what to do next' (9) and thus revealing psychological disorientation, she hints at the limitations of her sciencebased understanding of the island and its inhabitants. She criticizes her conduct by drawing attention to her 'total absorption of self' (42) at the beginning of her stay in Haiti. When reflecting on this behaviour, she concludes that she had adopted a 'conscience which had been selfish, not social' (42).

Through her internal questioning of Island Possessed's narrative authority, Dunham reconceptualizes the ethnographer as an uncertain translator of a culture whose complexities and contradictions are beyond her capacity to categorize, thereby destabilizing the narrative authority of scientific analysis by pointing to its inherently subjective qualities. One of Dunham's earliest experiences was seeing a bocor's spirit transfer, for example, which notably strained her powers of articulation. She allows that she has 'tried to write up a coherent form of experience of the bocor's spirit transference, but until now it has remained elusive, something which comes back to me over and over but which isn't clear in detail' (40). More particularly, when reflecting on the Haitian people's treatment of Estimé following his removal from power, she expresses concern about the island's collective mentality. She writes, 
I knew how Estimé had been loved, was still loved, and the fact that his life would be in danger even outside the country turned all the years that I had known Haiti into a mockery. I had dreamed of, written about, acquired property in, spread the good word far and wide about a country of which I really know nothing [emphasis added] (53).

In such passages, Dunham fundamentally questions her understanding of Haitian culture and life. In rejecting the traditional authorial certainty of the ethnographer, she hints at the limitations of anthropological inquiry, which, through scientific categorisation, risks failing to understand its subjects. This ambiguity is explored in detail in her complex relationship with Vodoun, in which she finds herself on a 'fringe border of belief and nonbelief' (105), an irreconcilable duality in which Dunham is both a sceptical observer and, by choosing to participate in a lavé-tête rite, an active and willing cultural participant.

During her lavé-tête, Dunham acts out a form of participant observation based on physical engagement into a collective experience. Her observations are channelled through shared corporal expression, and subjective physical sensation becomes a site of interpretation. Dunham emphasizes her physical and emotional state throughout the three-day lavé-tête ceremony by describing an 'aching from head to foot' as she lies on the 'damp floor' (68); later, she describes a sense of 'revulsion' and of feeling 'a little faint' (111) as she prepares for a ceremonial marriage to the Vodoun snake god Damballa. These striking descriptions of Dunham's initiation heighten the intensity of the experience and also underscore its psychological impact by emphasizing the subjectivity of her response to the event to destabilize scientific 
frameworks. Dunham relocates the subject of the observation from the cultural practice to the body and experience of the anthropologist, facilitating a shift from omniscient observation to autobiographical encounter.

Through her lavé-tête ceremony, therefore, Dunham experiences a transition from detached scientific observer to active, indeed intense, membership of a collective; of engagement with Haitian cultural experience through shared bodily immersion in religious ritual. Observing her fellow initiates, she writes, 'I was beginning to feel at home with them, to sense the tie of kinship that must hold together secret societies the world over' (79). Moreover, it is through physical interaction that she achieves communal acceptance and cultural inclusion as a dance ceremony serves as the ritual climax of her indoctrination into Vodoun. Dance serves a ritual purpose in Vodoun ceremonies, most notably by summoning up the loa, or spirits, who serve as intermediaries between the worshippers and their gods, and is the subject that Dunham arrived in Haiti to observe. During the collective dance ritual that forms the climax of her initiation, she finds herself in 'harmony with self and others', concluding that '[n]ow I was "out and above and beyond myself," dancing' (131). At the height of the dance ritual, she feels 'weightless, like Nietzsche's dancer, but unlike that dancer, weighted; transparent but solid, belonging to myself but a part of everyone else' (136). Kimerer L. LaMothe argues that, 'Nietzsche uses "dance” to represent a relationship to the body that revalues what he perceives as Christian hostility to bodily life' (2006: 2). She suggests that dancers such as Isadora Duncan (1877-1927) and Martha Graham (1894-1991) developed dance philosophies based on Nietzsche's work to create corporeal discourses of self-affirmation (2006: 2). But she fails to acknowledge Dunham's contribution in this regard. By engaging in a Vodoun ritual, Dunham, like Duncan and Graham before her, explores dance to reconfigure 
standard Christian mores that physically restrict human behaviour. In Dunham's case though, dance is a group practice that functions not only as a form of self-affirmation, but also to reclaim communal identity and social value; to revalue traditionally disregarded cultures.

Dunham's acceptance into Vodoun was driven by a perception on the part of her hosts that her ancestry connected her to them, and it is possible to infer that the intimacy of her experience was facilitated by her perceived racial heritage. Dunham notes the special attention that she receives as a perceived descendent of 'Nan Guinée' whose cultural heritage has been forgotten and lost, but which can be regained through rituals and through contact with the ancestors via Vodoun. She writes,

That I would come into their midst, able to worship these gods in dance, and knowing, if fragmentarily, the essences of the religion which had meant for them spiritual and, in periods of their history, physical survival ... seemed to be of utmost importance to the cult itself - as it was important that I carry the meaning of the true vaudun to my people in that other country (106-107).

Dunham's immersion in Vodoun was therefore at least in part made possible by her hosts' understanding that she would communicate its spiritual and cultural significance to U.S. African Americans. Her participation in dance rituals served as a key element in this exchange. Haitian dance rituals have historically functioned as physical expressions of psychological survival and as interpretative responses to the suffering brought about by enslavement. In her assessment of the social function of Vodoun, Joan Dayan reads the religion as a response to the horrors of slavery rather 
than as an expression of African survivals (1995: xvii), and suggests that:

For the 'possessed', that dance is not a loss of identity but rather the surest way back to the self, to an identity lost, submerged, and denigrated. In the horrors of the New World, the ability to know the god in oneself meant survival, which is nothing other than the ability to keep expressing the self, and acceding, if only temporarily, to a form of power that defies compromise (1995: 74).

Dunham's physical engagement with Vodoun enabled her to attain a remarkable degree of incorporation into her hosts' community, in turn providing her with a heightened understanding of a religious practice founded on re-establishing communal ties and individual self-worth following the traumas of enforced physical separation and human degradation. Through embodied communication in religious ritual, Dunham experiences a pioneering relationship between her anthropological subjects and herself as observer that defies traditional scientific hierarchies, as the social scientist must, at least in part, give in to the authority of her hosts and sublimate the gaze to the physical participation in dance ritual. Vodoun rituals demand that their members submit to the gods, thereby enabling participants to acquire an enhanced sense of community and inclusion by providing an active and important role for the individual within the group. At the climax of her initiation, Dunham takes part in what she describes as the 'signature dance' of Vodoun (135), the yonvalou, an ecstatic movement dedicated to the serpentine god Damballa in which the torso undulates like a snake and which leaves its practitioners in a 'state of complete submission and receptivity.' Under its 'hypnosis', Dunham is drawn to a state of such close physical contact with her fellow participants that, 'we gravitated to partners [...] knees pressed 
against the knees of someone else without even realizing the closeness' (135). By abandoning scientific observation in favour of embodied participation, Dunham therefore experiences a sense of intimate engagement with her hosts that enables her to experience cultural practices on a shared physical level. This egalitarian process of cross-cultural exchange based on shared bodily experience would later form the basis for Dunham's stage choreography, which decentred perceived dance hierarchies to express the artistic and cultural significance of folk dance forms.

I will now show how Dunham used what she learned in Haiti to develop a style of modernist dance that sought not to interpret Caribbean cultures as primitive practices readily available for artistic appropriation, but instead aestheticized these practices by instead reading them as sites of continual recreation and exchange. Dunham's Haitian research trip inspired her to introduce Caribbean dance forms and rituals onto the concert dance stage as she positioned her dance performances as the products of her anthropological research. Throughout a thirty-year international performance career, she underscored the artistry of African diasporic dance forms by presenting them on the stage and screen. She challenged artistic hierarchies by exploring cultural exchanges between Caribbean and South American rituals and ballet and modern dance practices. She developed a distinctive dance style, known as Dunham Technique, which was a complex blend of African and Caribbean dance patterns integrated with ballet and modern dance forms. Dunham Technique adapted dance rituals that Dunham experienced in Haiti, such as Yenvalou, Petra, and Congo, as training exercises, and one of her most famous performances was 'Shango', a staged translation of a Vodoun ritual that was first performed at the Adelphi Theater in New York in 1945, before forming part of her critically and commercially acclaimed four-year tour of post-war Europe. The artistic consequences of Dunham's 
Vodoun-inspired choreography were widely felt, both in Europe and in America. Robert Farris Thompson, who examines the religious origins of the 1950s Mambo dance craze, suggests that one particular Mambo movement, a sudden movement termed 'the head', was borrowed directly from Dunham's ritual-inspired choreography (2005: 343-344).

Dunham's efforts in bringing Haitian ritual dance forms before Haitian elites propagated an enthusiasm for these forms, not just in Haiti but around the world. As Michael Largey observes, 'While Dunham herself was not initially involved with Haitian tourism, her efforts to bring the yanvalou, kongo and mayi dances to Haitian dance stages had the indirect effect of cultivating a taste for Haitian dance among Haitian and foreign audiences' (2006: 202). Dunham's work directly inspired other dance stagings while she claimed that her collaboration with one of the twentieth century's most influential choreographers, George Balanchine, on 1940 Broadway musical Cabin in the Sky, shaped his ballet arrangements. Most notably, she suggested that her 'blatant use of the pelvic girdle', a physical movement popular in African and Afro-Caribbean dance cultures but held to be suggestive and risqué in European and American societies, 'put him at ease, let him do things he might not have done' (Hill 2005: 247).

Through its expression of the growing international black consciousness that Dunham experienced in Haiti, Island Possessed highlights her forgotten impact on the Black Arts Movement and sheds light on its elided international ramifications of the movement. During the 1960s, when Dunham wrote her memoir, she established an arts training programme for young people in East Saint Louis, one of the most economically depressed cities in the United States. She was also employed, through her friendship with Senegalese President and leading Négritude ideologist, Léopold 
Sédar Senghor (1906-2001), as United States representative to the first World Festival of Negro Arts in Senegal in 1966, an event that, like the Black Arts Movement, aimed to celebrate the cultural achievements of black people's African heritages. She also made plans for an arts academy on the Senegalese island of Gorée.

The First World Festival of Negro Arts took place over twenty-six days and featured thirty nations as well as a wide range of leading black thinkers and artists including Duke Ellington (1899-1974), Langston Hughes (1902-1967) and Wole Soyinka (1934-). A key symbolic event in celebrating and developing a Pan-African artistic consciousness, as Penny Von Eschen notes,

For many black American artists, the festival was more than simply a counterpart to African American art. Animated by the ideas of Négritude advocated by Senegal's poet-president Léopold Senghor, the festival was a celebration of the formal and spiritual connections between African and Afrodiasporic art forms, reflecting both the African inspirations and international resonances of developments in black American culture (2004: 150).

Although Dunham rejected notions of independent black institutions in favour of a more integrated approach to race relations, Island Possessed should be read as a literary product of her involvement in the Black Arts Movement. In a speech before the First World Festival of Negro Arts, she called for urgent attention to the cultural meanings of artistic expression, declaring that, 'because of the complex surrounding it, dance becomes more than any other art form the expression of the life of a people' (1966: 473). Dunham used the performative arts as a means of achieving social amelioration. She believed that providing dance education to deprived communities 
such as those in East St. Louis would teach young people the value of their artistic and cultural heritages, in turn providing them with a sense of confidence and selfrespect that would help to lift them out of poverty. As Sarah E. Johnson argues, 'Dunham was thus an integral figure of the Black Arts Movement of the 1960s and 1970s, using cultural production as a way of linking local struggles to international ones' (2005: 10). Correspondingly, she applied the Black Arts Movement's international cultural endeavours to local communities such as East St Louis to create a dynamic process of education through the arts which was based on intercultural exchange.

As well as being a key player in the Festival and the wider aims of the Black Art Movement more generally, Dunham should also be recognized as an instigator of the African cultural revolution that made it possible. In her 1979 biography, Ruth Beckford records a 1965 conversation between Dunham and President Senghor in which she notes that Dunham's touring dance performances in the late 1940s and early 1950s inspired chiefs-of-state in sub-Saharan Africa to develop their own culturally celebratory artistic formulas (1979: 404). The welcome that Dunham received when she arrived in Senegal led directly to her work with the Festival, and she made three trips to Dakar in 1966 as a United States specialist. Beckford points out that, 'In Senegal in 1966 she realized that she had aided in spearheading Africa's cultural revolution. Furthermore, she felt that she belonged to the African intellectual complex and wanted to understand and develop with the African country' (1979: 405). As further evidence, Dunham adhered to this commitment to Senegalese culture by remaining in the country in the late 1960s and working to develop its national ballet.

In a 1988 seminar on Dunham Technique, Dunham outlined plans to extend 
Black Arts Movement goals to Haiti itself by establishing an institute for intercultural communication on the island (Dunham 1988). Although Dunham's plans never came to fruition, her philosophy of intercultural exchange had a significant indirect impact on Haiti's artistic identity. Dunham fostered the international career of Haitian dancer, Jean Léon Destiné (c1920s-), a leading exponent of Haitian dance in the United States who was also responsible for establishing a government-sponsored National Folklore Troupe in Haiti. Destiné befriended leading black intellectuals such as Paul Robeson (1898-1976) and Langston Hughes (1902-1967), and worked on African American composer William Grant Still's Haiti-set opera, Troubled Island, which was staged by the New York City Opera in 1949. Polyné argues that, 'The dancer's widespread popularity enabled him to entertain and educate U.S. audiences about Haitian folkloric dance and Haitian progress and also helped him continue to establish relationships with U.S. African American intellectuals and artists' (2010: 166).

In 1953, another Dunham dancer, Lavinia Williams Yarborough (1916-1989), founded the Haitian Institute of Folklore and Classic Dance and served as director of the island's Théatre de Verdure, where she developed dance forms that were based on Vodoun rituals. Williams Yarborough also founded national schools of dance in several Caribbean countries, was a faculty member at New York University and helped to set up the National School of Dance of Haiti and the Ballet National d'Haiti. As Lynne Fauley Emery notes, 'The contribution of Lavinia Williams Yarborough to black concert dance is twofold: first, she has preserved the authentic folk forms of the West Indies; and second, she has prepared dancers, many of whom eventually perform on the stages of American theaters' (1988: 330).

Polyné positions both Destiné and Williams Yarborough as key figures in the 
foregrounding and enhancement of Haiti's artistic consciousness, both at home and abroad, during the mid-twentieth century. He writes,

During the 'golden age' of Haitian tourism, from the late 1940s to 1956, Destiné and Williams transformed the pedagogy of Haitian folkloric dance by establishing national institutions in Haiti that imparted technical discipline to this folk art form ... the establishment of cultural institutions and the training of Haitian dancers affirmed the creation of an alternative world by black dancers in which African-based art forms were celebrated and in consistent dialogue with Western culture (2010: 157-58).

Polyné admits that Dunham was key in shaping both of these dancers' careers, and that the roots of their achievements can be found in Dunham's work. Destiné spent two years with Dunham on her Broadway and international touring production, Bal Negre (1946), before forming his own dance company. Noting that 'Williams' experience in the Dunham Company profoundly influenced her understanding of dance and the ethnology of dance in countries with people of African descent', Polyné argues that she developed a dance philosophy that adopted an ethnological approach based on an understanding of the 'form and function' of folk dance practices in order to foster community cohesion and artistic appreciation of Caribbean folk cultures (2010: $171 \&$ 177). This method was remarkably similar to Dunham's internationalist and socially inclusive approach to dance, which sought to celebrate Caribbean performance cultures and facilitate intercultural exchange by pointing up artistic and psychological significances of the islands' dance practices.

One final Dunham protégé who would make a substantial contribution to the 
cultural recognition of Vodoun was avant-garde filmmaker and anthropologist Maya Deren. Deren, who began work as Dunham's personal secretary in the early 1940s, visited Haiti three times between 1947 and 1954 to document Vodoun. Her anthropological account of Haitian life, Divine Horseman: Living Gods of Haiti (1953), remains a leading scholarly text on Vodoun - Dunham herself described it as 'one of the classics on Haitian folk and religious custom' - and the unfinished film that Deren made to accompany her book offers a rare visual record of Haitian rara festivals (Dunham 1984-1985). Deren's experiences of Vodoun formed the basis of a combined exploration of dance and cinema as well as the development of a filmic practice that downgraded the traditionally privileged human subject in favour of the wider significance of the filmic 'ritual'. As she noted in 'An Anagram of Ideas on Art, Form and Film' (1946),

The ritualistic form treats the human being not as the source of the dramatic action, but as a somewhat depersonalized element in a dramatic whole. The intent of such depersonalization is not the destruction of the individual; on the contrary, it enlarges him beyond the personal dimension and frees him from the specializations and confines of personality. He becomes part of a dynamic whole which, like all such creative relationships, in turn, endow its parts with a measure of its larger meaning (20) (Nichols 2001: 10). ${ }^{\mathrm{i}}$

In Vodoun, Deren discovered a platform by which to further Dunham's exploration of the arbitrary nature of social and cultural hierarchies. Like Dunham, she explored the fluidity of identities through communal interaction and exchange.

Island Possessed therefore sheds light on a much wider lifelong project 
undertaken by Dunham, namely her attempt to enact an artistic legitimisation of Haiti by incorporating its ritual dance forms onto the concert dance stage. Her work would significantly undermine perceived cultural binaries by ensuring a significant Haitian cultural influence over North American dance throughout the mid-twentieth century. In the text, Dunham shows evidence of a heightened and self-reflexive sensitivity towards Caribbean dance cultures that acknowledges its dynamism as well as its contemporary significance to practitioners. In this regard, the work marks an important literary illumination of the links between her anthropological work and dance philosophy.

In the midst of writing Island Possessed, and at the height of the Black Arts Movement, Dunham outlined her plans for a dance academy on Gorée. She conceived of the project as a means of revaluing African dance forms and of drawing international attention to the complex social and artistic lives of their practitioners, declaring that, 'The arts, visual and performing, are, because of their freedom from language barriers among the most effective agents of contact, communication and persuasion' (Dunham 1965). Island Possessed is a valuable articulation of Dunham's dance philosophy, in which she used her anthropological knowledge of dance to enhance understandings of the diversities and complexities of human experiences. As an ethnographic memoir, it is deeply entrenched in problematizing scientific representations of Haitian lives. Dunham articulates a deeply ambivalent, disconcerting narrative voice that confronts its own uncertainties and subjectivities. By reconfiguring her role from a detached observer to that of an active participant who literally embodies the cultural rites of her hosts, Dunham challenges historical objectifications of sociological subjects to blur the boundaries between self and other. In her memoir, therefore, Dunham enacts a play on cultural and racial categorisations 
that articulates the complexities of its human subjects, facilitating a career based on intercultural exchange that would foster a lifelong personal and professional relationship between Dunham and Haiti, and stimulate a significant and enduring Vodoun contribution to international dance practices.

\section{$\underline{\text { Acknowledgements }}$}

My heartfelt thanks go to Dr Celeste-Marie Bernier for taking the time to read and comment on a draft of this article. 


\section{$\underline{\text { References }}$}

Aschenbrenner, Joyce (2002), Katherine Dunham: Dancing a Life, Urbana: University of Illinois Press.

Beckford, Ruth (1979), Katherine Dunham: A Biography, New York: Marcel Dekker.

Clifford, James (1986), 'Introduction: Partial Truths', Writing Culture: The Poetics and Politics of Ethnography, ed. James Clifford and George E. Marcus, Berkeley: University of California Press, 1-26.

(1988), The Predicament of Culture: Twentieth-Century Ethnography, Literature, and Art, Cambridge: Harvard University Press.

Dayan, Joan (1995), Haiti, History, and the Gods, Berkeley: University of California Press.

Dunham, Katherine (1947), Las danzas de Haiti/Dances of Haiti, Los Angeles: Center for Afro-American Studies at UCLA, 1983.

(1969), Island Possessed, Chicago: University of Chicago Press, 1994. 
([1941] 2005), 'Form and Function in Primitive Dance',

Educational Dance 4: 10, 2-4. Kaiso!: Writings by and about Katherine Dunham, ed. VèVè A. Clark and Sara E. Johnson, Madison: The University of Wisconsin Press, 502-07.

([1984-1985] 2005), 'Early New York Collaborations: Excerpt from "Minefields,", Kaiso!, ed. Clark and Johnson, 125-149.

(c.1963), Island Possessed - Original Notes, Folder 1.

Katherine Mary Dunham Papers, Special Collections, Morris Library, Southern Illinois University, Carbondale.

(1966), 'The Performing Arts of Africa', Colloquium: Function and Significance of African Negro Art in the Life of the People and for the People, $1^{\text {st }}$ World Festival of Negro Arts, Dakar, 1-24 April 1966, 473-80.

([1965] 2005), 'Plan for an Academy of West African Cultural Arts', from 'Plan for Gorée as Residence Academy for West African Cultural Arts', Kaiso!, ed. Clark and Johnson, 407-11.

(1988), 'Talking about Haiti'. Katherine Dunham Seminar, East St. Louis. Katherine Dunham Collection, Moving Image Section, Motion Picture, Broadcasting and Recorded Sound Division, Library of Congress, Washington, D.C. 
Emery, Lynne Fauley (1988), Black Dance from 1619 to Today, Hightstown, New Jersey: Dance Horizon Books.

Fischer-Hornung, Dorothea (2008), “"Keep Alive the Powers of Africa”: Katherine Dunham, Zora Neale Hurston, Maya Deren, and the Circum-Caribbean Culture of Vodoun', Atlantic Studies, 5: 3, 347-62.

Hill, Constance Valis (2005), 'Collaborating with Balanchine on Cabin in the Sky: Interviews with Katherine Dunham', Kaiso!, ed. Clark and Johnson, 235-47.

Johnson, Sara E. (2005), 'Introduction: Diamonds on the Toes of Her Feet', Kaiso!, ed. Clark and Johnson, 3-15.

Köpping, Klaus-Peter (2002), Shattering Frames: Transgressions and Transformations in Anthropological Discourse and Practice, Berlin: Reimer.

Lamothe, Daphne (2008), Inventing the New Negro: Narrative, Culture, and Ethnography, Philadelphia: University of Pennsylvania Press.

LaMothe, Kimerer L. (2006), Nietzsche's Dancers: Isadora Duncan, Martha Graham, and the Revaluation of Christian Values, Gordonsville: Palgrave Macmillan.

Largey, Michael (2006), Vodoun Nation: Haitian Art, Music and Cultural Nationalism, Chicago: The University of Chicago Press. 
Murray, David (2007), Matter, Magic and Spirit: Representing Indian and African American Belief, Philadelphia: University of Pennsylvania Press.

Nichols, Bill (2001), Maya Deren and the American Avant-Garde (Berkeley: University of California Press.

Osumare, Halifu (2005), 'Katherine Dunham, a Pioneer of Postmodern Anthropology', Clark and Johnson (eds.), Kaiso!, 612-23.

Polyné, Millery (2010), From Douglass to Duvalier: U.S. African Americans, Haiti, and Pan Africanism, 1870-1964, Gainesville: University of Florida.

Ramsey, Kate (1997), 'Vodou, Nationalism, and Performance: The Staging of Folklore in Mid-Twentieth-Century Haiti', Meaning in Motion: New Cultural Studies of Dance, ed. Jane C. Desmond, Durham: Duke University Press, 345-78.

Rao, Ursula, and John Hutnyk (2006), 'Introduction', Celebrating Transgression: Method and Politics in Anthropological Studies of Culture: A Book in Honour of Klaus-Peter Köpping, ed. Ursula Rao and John Hutnyk, New York: Berghahn Books, $1-10$.

Robeson, Eslanda Goode (1946), African Journey, London: Victor Gollancz.

St. John, Sir Spenser (1884), Hayti; Or, the Black Republic, London: Smith, Elder, \& Co. 
Thompson, Robert Farris (2005), 'Teaching the People to Triumph Over Time', Caribbean Dance from Abakua to Zouk: How Movement Shapes Identity, ed. Susanna Sloat, Gainesville: University Press of Florida.

Von Eschen, Penny M. (2004), Satchmo Blows Up the World, Cambridge: Harvard University Press. 